\title{
Blood Calcium Level and Its Correlation with Calcium Daily Intake, Calcium Supplementation \& Clinical Symptoms in Women with Premenstrual Syndrome
}

\author{
Meilinah Hidayat*, Komang R.P.Wardani**, Bertha M.Purba**, \\ Rendhy T.Apreza** \\ **Nutrition Department Faculty of Medicine Maranatha Christian University \\ *Faculty of Medicine Maranatha Christian University \\ Jl. Prof. Drg. Suria Sumantri MPH No. 65 Bandung 40164 Indonesia \\ Email:mellahidayat@yahoo.com
}

\begin{abstract}
Premenstrual syndrome (PMS) is complex of symptoms that occur during the luteal phase of the menstrual cycle. This study aimed to observe blood calcium levels differences between the patient and not the PMS, list the average intake of calcium / day among subjects, statistically analyze the relationship between calcium intake and blood calcium levels, and examine the effect of calcium supplementation on blood calcium levels and symptoms of PMS. We examined blood levels of calcium, analytical survey method using a cross-sectional study, experimental methods and PMS symptom questionnaires. The results showed that in the group of subjects SPM average blood calcium level, and the mean intake of calcium / day were lower than in non-PMS and showed a fairly correlation between the intake of calcium per day with blood calcium levels in SPM subjects. There is a significant relationship between increased calcium blood calcium levels and symptoms of PMS. The conclusions: 1. there are differences in blood calcium levels and 2. intake of calcium per day between patients with PMS and not PMS, 3. Calcium intake is significantly associated with calcium level in the PMS and 4. calcium supplementation affects blood calcium levels and reduce symptoms of PMS.
\end{abstract}

Keywords : $\quad$ average calcium intake, blood calcium, calcium supplementation, Premenstrual Syndrome (PMS), 


\title{
Kadar Kalsium Darah dan Hubungannya dengan Asupan Kalsium per Hari, Pemberian Suplemen Kalsium dan Gejala Klinik pada Mahasiswi dengan Sindroma Premenstruasi
}

\author{
Meilinah Hidayat, Komang Resty Pramudia Wardani**, Bertha Melisa Purba**, \\ Rendhy Tito Apreza** \\ **Bagian Nutrisi Fakultas Kedokteran Universitas Kristen Maranatha \\ **Fakultas Kedokteran Universitas Kristen Maranatha \\ J1. Prof. Drg. Suria Sumantri MPH No. 65 Bandung 40164 Indonesia \\ Email : mellahidayat@yahoo.com
}

\begin{abstract}
Abstrak
Sindroma premenstruasi (SPM) adalah sekumpulan gejala kompleks yang terjadi selama fase luteal dari siklus menstruasi dan berkurang setelahnya. Tujuan penelitian ini untuk mengetahui perbedaan kadar kalsium darah antara, rerata asupan kalsium/hari, hubungan antara asupan kalsium dengan kadar kalsium darah pada penderita dan bukan penderita SPM , serta pengaruh pemberian suplemen kalsium terhadap kadar kalsium darah dan gejala SPM. Metode pemeriksaan adalah survei analitik dengan desain potong-lintang, eksperimental dan kuesioner terhadap gejala SPM. Hasil penelitian menunjukkan bahwa kadar rerata kalsium darah kelompok subjek SPM: 8,637 mg/dL dan rerata asupan kalsium/hari 723,65 mg/hari, pada bukan SPM 9,003 mg/dL dan 894,50 mg/hari dan menunjukkan hubungan yang cukup $(\mathrm{r}=0,615)$ antara asupan kalsium per hari dengan kadar kalsium darah pada subjek SPM. Terdapat hubungan signifikan $(\mathrm{p}<0.05)$ antara pemberian suplemen kalsium dengan kadar kalsium darah dan penurunan gejala SPM. Simpulan penelitian ini terdapat perbedaan kadar kalsium darah dan jumlah asupan kalsium per hari yang signifikan antara penderita SPM dan bukan SPM, asupan kalsium berhubungan sangat signifikan dengan kadar kalsium darah pada kejadian SPM dan pemberian suplemen kalsium memengaruhi kadar kalsium darah serta menurunkan gejala SPM.
\end{abstract}

Kata kunci : kalsium darah, rerata asupan kalsium, Sindroma Premenstruasi (SPM), suplemen kalsium 


\section{Research Article}

\section{Pendahuluan}

Sindroma Premenstruasi (SPM) merupakan salah satu gangguan yang paling umum dialami oleh wanita; secara luas diartikan sebagai gangguan siklik berulang berkaitan dengan variasi hormonal perempuan dalam siklus menstruasi, yang berdampak pada emosional dan kesejahteraan fisik selama masa reproduksinya. Sebanyak 30-50\% dari wanita mengalami gejala SPM, sekitar 5\% merasakan gejala yang cukup parah, dan 10\% mengalami gejala yang sangat parah hingga menyebabkan ketidakhadiran di sekolah atau tempat kerja selama 1-3 hari setiap bulannya. ${ }^{1}$ Sindroma ini ditandai dengan sekelompok tanda dan gejala yang kompleks, yang terjadi selama fase luteal dari siklus menstruasi dan berkurang segera setelah onset menstruasi. Gejala ini umumnya akan muncul kembali pada menstruasi yang akan datang. kumpulan gejala yang timbul meliputi gejala fisik, psikologis dan emosi; umumnya berupa depresi, perasaan sensitif berlebihan, lemah badan, kram perut, breast tenderness, gangguan mood dan sakit kepala. $^{2}$

Sekitar 80 hingga 95\% perempuan pada usia reproduksi yaitu 14-59 tahun mengalami gejala-gejala premenstruasi yang dapat mengganggu beberapa aspek dalam kehidupannya. Gejala tersebut dapat diperkirakan dan biasanya terjadi secara regular pada periode dua minggu sebelum menstruasi. Hal ini dapat hilang begitu dimulainya pendarahan, namun dapat pula berlanjut setelahnya. Pada sekitar 14\% perempuan antara usia 20 hingga 35 tahun, SPM dapat berpengaruh sangat hebat sehingga mengharuskan mereka beristirahat dari sekolah atau pekerjaannya. Penelitian di Surabaya pada tahun 2006 menunjukkan sebanyak 60,8\% remaja putri SMU mengalami SPM ringan dan sebanyak 39,2\% mengalami SPM berat. ${ }^{3}$ Penelitian lainnya menunjukkan 71,93\% siswi SLTP di Semarang mengalami SPM. ${ }^{4}$

Penyebab yang pasti dari SPM masih belum jelas, akan tetapi ada yang mengaitkan dengan zat gizi tertentu seperti gangguan metabolisme asam lemak esensial ataupun kekurangan vitamin B6 dan mineral kalsium. ${ }^{5}$ Kalsium, dikatakan berpengaruh terhadap gangguan mood dan perilaku yang berlangsung selama SPM. Gejala-gejala seperti kegelisahan, dehidrasi, dan depresi menyembuh pada penderita SPM yang mengonsumsi kalsium. ${ }^{6}$ Sebuah penelitian yang dilakukan oleh Bertone-Jhonson dkk tahun 2005 terhadap perempuan berusia 27 - 44 tahun menunjukkan bahwa pemenuhan kebutuhan kalsium dan vitamin D harian dapat mengatasi masalah SPM ini. ${ }^{2}$ Kadar kalsium dan vitamin D dalam darah pada perempuan yang mengalami SPM lebih rendah dari kadar normal sehingga suplementasi kalsium bisa mengurangi keparahan gejala yang dialami. ${ }^{2}$ Dari penelitian Shamberger yang mengamati 46 penderita SPM dengan usia rata-rata 36,2 tahun dan 50 perempuan normal dengan usia rata-rata 37,7 tahun, didapatkan 


\section{Research Article}

kadar kalsium darah pada penderita SPM lebih rendah secara signifikan, dibandingkan dengan perempuan normal. $^{7}$

Penelitian pada mahasiswi Fakultas Kedokteran ini perlu dilakukan karena SPM menurunkan produktivitas, sementara mahasiswi kelompok rentang usia antara 19 - 25 tahun dengan tuntutan produktivitas yang tinggi, belum banyak diteliti. Mahasiswi termasuk golongan yang rentan mengalami SPM karena memiliki tingkat stres yang lebih tinggi dibanding remaja dan pola makan bertendensi kurang baik dikarenakan memiliki tingkat kesibukan yang tinggi, sehingga cenderung mengalami kekurangan sejumlah zat gizi mikro dan vitamin. Mahasiswi Fakultas Kedokteran, sejatinya sebagai subjek penelitian sudah banyak mengetahui mengenai manfaat dan kepentingan mineral kalsium, akan tetapi masih banyak yang belum mengetahui hubungannya dengan SPM. Dengan penelitian ini diharapkan mahasiswi lebih memperhatikan kecukupan nutrisinya agar terhindar dari SPM.

\section{Metode}

Desain Penelitian menggunakan teknik potong-lintang. Pengukuran kadar kalsium dilakukan dengan prinsip kolorimetri metode $O$-cresolphthalein complexone dan metode survei analitik. Pengukuran yang diamati adalah kondisi pada saat penelitian dilakukan. Sampel penelitian yang digunakan meliputi data formulir kuesioner untuk subjek penelitian, meliputi data pribadi, nama, usia, dan riwayat gejala SPM, darah vena yang diambil dari subjek penelitian sebagai bahan pemeriksaan kadar kalsium darah, form wawancara untuk food recall 24 jam dan food frequency 30 hari. Bahan dan kelengkapan penelitian, berupa tablet kalsium laktat yang mengandung $500 \mathrm{mg}$ Kalsium, dan formulir informed consent. Data diambil dari subjek penelitian dengan cara pengisian kuesioner riwayat gejala SPM, kemudian dipilih 60 subjek penelitian yang telah memenuhi kriteria inklusi dan eksklusi terdiri atas 30 mahasiswi Fakultas Kedokteran SPM dan 30 bukan SPM, kemudian dilakukan wawancara pola asupan makan dengan metode pengisian riwayat asupan makan selama 24 jam dan frekuensi makanan 30 hari, pengambilan darah vena untuk pemeriksaan kalsium darah dilakukan dalam siklus menstruasi hari ke-2 (untuk keseragaman). ${ }^{8,9}$ Pelaksanaan penelitian ini telah disetujui dan diizinkan oleh Komisi Etik Penelitian FK Universitas Maranatha SK no: 164/KEP FK UKMRSI/IV/2011.

Untuk mengetahui efek pemberian suplemen kalsium terhadap kadar kalsium darah dan gejala SPM digunakan metode eksperimental Rancang Acak Lengkap dan kuesioner gejala SPM yang merupakan modifikasi pertanyaan kuesioner yang dipakai pada penelitian Brahmbhatt. ${ }^{10,11}$ 


\section{Research Article}

Variabel dependen dalam penelitian ini adalah kadar kalsium darah dan gejala SPM. Variabel independen penelitian adalah dosis suplemen kalsium. Terhadap subjek penelitian dilakukan pendataan tentang riwayat gejala SPM menggunakan instrumen kuesioner dan pemeriksaan kadar kalsium dalam darah sebelum dan 14 hari sesudah pemberian suplemen Kalsium. Subjek penelitian berjumlah 28 orang mahasiswi dengan riwayat SPM yang telah memenuhi kriteria inklusi dan kriteria eksklusi, dibagi menjadi 4 kelompok perlakuan, yaitu kelompok I (kontrol negatif), kelompok II (kalsium 500 mg/hr), kelompok III (kalsium 1.000 $\mathrm{mg} / \mathrm{hr}$ ), dan kelompok IV (kalsium $2.000 \mathrm{mg} / \mathrm{hr}$ ). Pemeriksaan dilakukan di Laboratorium Prodia dan Poliklinik Universitas Kristen Maranatha. ${ }^{11}$

\section{Analisis Data}

Data yang diperoleh dianalisis menggunakan uji beda dua rata-rata yaitu uji t tidak berpasangan, ${ }^{8}$ Data hasil perhitungan asupan kalsium per hari dan kalsium dalam darah yang telah diperoleh diolah menggunakan crosstab, dianalisis secara deskriptif dalam bentuk tabel. ${ }^{9}$ Data asupan kalsium per hari, dan kalsium dalam darah subjek SPM dan bukan SPM dianalisis menggunakan uji t tidak berpasangan, dengan $\alpha=0,05$. Hubungan antara rerata asupan kalsium per hari dengan kalsium dalam darah dianalisis menggunakan korelasi Pearson dan regresi linier sederhana dengan $\alpha \leq 0,05.8$

Untuk mengetahui efek pemberian suplemen kalsium terhadap peningkatan kadar kalsium darah, selain itu untuk mengetahui apakah kadar kalsium darah mempengaruhi gejala SPM, dilakukan uji Kruskal Wallis dan dilanjutkan dengan uji Mann Whitney. ${ }^{10}$

\section{Hasil}

Terhadap subjek penelitian dilakukan pendataan tentang riwayat gejala SPM melalui instrumen kuesioner selanjutnya diperiksa kadar kalsium dalam darahnya di Laboratorium Prodia Poliklinik Universitas Kristen Maranatha. ${ }^{8,9}$ Tahap selanjutnya dilakukan pemeriksaan anamnesis meliputi kuesioner data pribadi, riwayat asupan makan 24 jam dan frekuensi makanan 30 hari. ${ }^{9}$

\section{Hasil Pemeriksaan Kadar Kalsium dalam Darah}

Pemeriksaan kadar Kalsium dalam serum dilakukan secara kuantitatif menggunakan prinsip kolorimetri dan metode $O$-cresolphthalein complexone. Rentang kadar kalsium darah normal menurut Laboratorium Prodia tempat pemeriksaan dilakukan adalah antara 8,8 - 10,2 $\mathrm{mg} / \mathrm{dL}$. Hasil pemeriksaan kadar kalsium dalam darah 30 subjek penelitian yang memiliki 
riwayat SPM dan 30 subjek penelitian yang tidak memiliki riwayat SPM reratanya dapat dilihat pada tabel 1 di bawah ini. ${ }^{8}$

Tabel 1 Hasil Pemeriksaan Kadar Kalsium Darah 30 Subjek yang SPM dan 30 Subjek yang SPM ${ }^{8}$

\begin{tabular}{lcccc}
\hline & $\begin{array}{c}\text { Subjek yang SPM } \\
(\mathrm{mg} / \mathrm{dL})\end{array}$ & $\begin{array}{c}\text { Subjek } \\
(\mathrm{mg} / \mathrm{dL})\end{array}$ & yang \\
\hline Rerata Kadar Kalsium & & 8,64 & 9,00 \\
\hline
\end{tabular}

Dari 30 subjek penelitian yang memiliki riwayat SPM, sebanyak 17 subjek (57\%) tergolong defisiensi kalsium dan 13 subjek tergolong normal (43\%). Rerata kadar kalsium dalam darah untuk 30 subjek penelitian yang tidak memiliki riwayat SPM adalah 9,003 mg/dL dan rerata kadar kalsium darah untuk 30 subjek penelitian yang memiliki riwayat SPM adalah $8,637 \mathrm{mg} / \mathrm{dL}$. Setelah dilakukan analisis uji t tidak berpasangan, hasilnya menunjukkan nilai $\mathrm{t}$ hitung 3,125 lebih besar dari $\mathrm{t}$ tabel 2,000 ( $\mathrm{p}=0,003)$, berarti terdapat perbedaan yang signifikan antara rerata kadar Kalsium darah penderita dengan SPM dan bukan SPM. ${ }^{8}$

\section{Hasil Penghitungan Rerata Asupan Kalsium per Hari ${ }^{9}$}

Pemeriksaan asupan Kalsium per hari berdasarkan anamnesis meliputi kuesioner data pribadi, riwayat asupan makan 24 jam dan frekuensi makanan jangka waktu 30 hari. Setelah dilakukan penghitungan asupan Kalsium per hari terhadap 30 subjek penelitian yang memiliki riwayat SPM dan 30 subjek penelitian yang tidak, didapat hasil yang reratanya dapat dilihat pada tabel 2 di bawah ini

Tabel 2 Hasil Penghitungan Asupan Kalsium per hari dari 30 Subjek yang SPM dan 30 Subjek yang tidak SPM ${ }^{9}$

\begin{tabular}{lccc}
\hline & $\begin{array}{l}\text { Subjek yang SPM } \\
(\mathrm{mg} / \mathrm{hari})\end{array}$ & $\begin{array}{l}\text { Subjek yang tidak } \\
\text { SPM (mg/hari) }\end{array}$ \\
\hline Rerata Asupan Kalsium & & 723,65 & 894,50 \\
\hline
\end{tabular}

Didapat hasil rerata asupan kalsium pada 30 subjek penelitian yang tidak memiliki riwayat SPM adalah $894,50 \mathrm{mg} /$ hari dan rerata asupan kalsium pada 30 subjek penelitian yang memiliki riwayat SPM adalah 723,65 mg/hari lalu dilakukan analisis statistik menggunakan uji t tidak berpasangan dan didapatkan nilai t hitung 2,441, yang lebih besar dari t tabel 2,000 maka disimpulkan bahwa asupan kalsium pada subjek penelitian yang memiliki riwayat SPM berbeda 


\section{Research Article}

secara signifikan $(p=0,019)$ dibandingkan dengan asupan kalsium pada subjek penelitian yang tidak memiliki riwayat SPM. ${ }^{9}$

\section{Hubungan Asupan Kalsium dengan Kalsium Darah pada Penderita SPM ${ }^{9}$}

Dari hasil asupan kalsium per hari dilakukan analisis hubungannya dengan kalsium dalam pada mahasiswi dengan SPM darah. Analisis statistik yang digunakan adalah korelasi Pearson yang dapat dilihat pada tabel 3 .

Tabel 3 Hasil Analisis Statistik Korelasi dan Regresi Hubungan antara Asupan dan Kadar Kalsium Darah Penderita SPM ${ }^{9}$

\begin{tabular}{|c|c|c|c|c|c|}
\hline \multicolumn{3}{|c|}{ Pearson } & \multicolumn{3}{|c|}{ Regresi Linier } \\
\hline Hubungan & $\mathbf{r}$ & $p$ & A (konstanta) & B & R square \\
\hline $\begin{array}{l}\text { Asupan makan dan } \\
\text { Kadar kalsium darah }\end{array}$ & 0,615 & 0,000 & 7,511 & 0.002 & 0,378 \\
\hline $\begin{array}{l}\text { Kriteria Guilford dilihat berdasark } \\
<0,2 \text { Negligible Relationship } \\
0,2-<0,4 \text { Low relationship } \\
0,4-<0,7 \text { Moderate relationship } \\
0,7-<0,9 \text { High relationship } \\
>0,9 \text { Very high relationship }\end{array}$ & n r (koefis & korelasi) & & & \\
\hline $\begin{array}{l}\text { Keterangan : } \\
\text { A : konstanta } \\
\text { B : koefisien regresi }\end{array}$ & & & & & \\
\hline
\end{tabular}

Pada tabel 3 dari hasil analisis statisik didapatkan hubungan antara asupan kalsium dengan kalsium dalam darah pada 30 subjek penelitian dengan riwayat SPM dengan nilai $\mathrm{p}=$ 0,000 , berarti terdapat hubungan yang sangat signifikan dengan koefisien korelasi (r) sebesar 0,615. Berdasarkan kriteria Guilford, 0,615 menunjukkan hubungan yang cukup.

Untuk mengetahui pengaruh dari asupan kalsium per hari terhadap kalsium dalam darah, dilakukan analisis statistik dengan regresi linier sederhana sehingga didapatkan persamaan sebagai berikut: $\mathbf{y}=\mathbf{a}+\mathbf{b x}$ jadi kalsium dalam darah pada non SPM $=7,511+0,002$ asupan kalsium, dimana artinya adalah setiap kenaikan 1 Unit (mg) asupan kalsium per hari akan menambahkan 0,002 mg kalsium dalam darah. ${ }^{9}$ Analisis statistik korelasi Pearson dan regresi linier sederhana menunjukkan bahwa adanya hubungan yang signifikan dan cukup antara asupan kalsium per hari dengan kalsium dalam darah pada penderita SPM.

Hasil ini sejalan dengan penelitian Jacobs dan Susan tahun 2000 yang menyatakan bahwa pemberian kalsium terbukti menunjukkan 50 persen pengurangan gejala SPM. Asupan tinggi kalsium sebesar $1.336 \mathrm{mg} / \mathrm{hari}$ dapat memperbaiki gejala-gejala gangguan mood, perilaku, nyeri, dan retensi air selama siklus menstruasi. Penelitian selama beberapa tahun terakhir menunjukkan bahwa berbagai nutrisi memiliki peran penting dalam masalah mood dan gangguan perilaku dari SPM, contohnya kalsium dan vitamin D. Hormon-hormon di ovarium 


\section{Research Article}

mempengaruhi metabolisme kalsium, magnesium, dan vitamin D. Estrogen mengatur metabolisme kalsium, penyerapan kalsium di intestinal dan sekresi paratiroid dan hasil akhirnya estrogen menurunkan kadar kalsium serum. Peningkatan kadar estrogen akan mengakibatkan turunnya konsentrasi kalsium dengan kompensasi kenaikan hormon paratiroid dalam mencegah terjadinya hipokalsemia. ${ }^{1}$ Pada saat menstruasi, perempuan akan kehilangan kalsium dalam darah, sehingga untuk mengganti kalsium dan menjaga keseimbangan kalsium dalam darah diperlukan asupan kalsium dari makanan. ${ }^{12}$

\section{Hasil Pemeriksaan Kadar Kalsium Darah Sebelum dan Sesudah Pemberian Suplemen Kalsium}

Hasil pemeriksaan kadar kalsium darah dari 28 subjek penelitian yang diperiksa di Laboratorium Prodia Poliklinik Universitas Kristen Maranatha tercantum pada Tabel $4 .{ }^{10}$

\section{Tabel 4 Rerata Kadar Kalsium Darah Sebelum dan Sesudah Pemberian Suplemen Kalsium ${ }^{10}$}

\begin{tabular}{lccc}
\hline Kelompok & Sebelum (mg/dL) & Sesudah (mg/dl) & Selisih (mg/dL) \\
\hline I Kontrol Negatif & 8,83 & 8,81 & $-0,02$ \\
II Pemberian Kalsium 500 mg/hari & 9,23 & 9,39 & 0,16 \\
III Pemberian Kalsium1.000 mg/hari & 9,04 & 9,36 & 0,32 \\
IV Pemberian Kalsium 2000 mg/hari & 9,01 & 9,47 & 0,46 \\
\hline
\end{tabular}

Dari tabel-tabel di atas, diketahui bahwa peningkatan kadar kalsium tertinggi didapatkan pada kelompok IV. Untuk mengetahui apakah pemberian suplemen kalsium dapat meningkatkan kadar kalsium dalam darah, maka dilakukan uji Kruskal Wallis berdasarkan hasil pemeriksaan kadar kalsium darah, dan hasilnya $F$ hitung $18,611, p=0,00$. Nilai $p \leq 0.05$ menunjukkan bahwa terdapat perbedaan yang signifikan antara kelompok kalsium dengan kontrol. Kemudian dilanjutkan dengan uji Mann Whitney. Hasil yang didapat: pada kelompok III dan IV terdapat perbedaan yang bermakna dengan kelompok kontrol ( $\mathrm{p}<0,05)$. Kelompok III dan IV tidak terdapat perbedaan yang bermakna antara satu sama lain $(p>0,05)$. Hal ini menunjukkan bahwa kelompok yang diberi Kalsium 1000 mg/hari dan 2000 mg/hari memiliki efek yang setara dalam meningkatkan kadar kalsium dalam darah. ${ }^{10}$ 


\section{Pemeriksaan dan Perhitungan Skor Gejala SPM Sebelum dan Sesudah Pemberian Suplemen Kalsium}

Terhadap 28 orang subjek penelitian dengan SPM diberikan kuesioner sebelum dan sesudah pemberian suplemen Kalsium selama 14 hari, yang meliputi: Identitas responden terdiri dari 4 pertanyaan, riwayat SPM terdiri dari 7 pertanyaan, gejala SPM terdiri dari 18 pertanyaan, yang merupakan modifikasi pertanyaan gejala klinik dalam penelitian Brahmbhatt, selanjutnya jawaban pertanyaan dihitung dalam bentuk skor. Hasil penghitungan skor gejala SPM sebelum (Kuesioner I) dan sesudah (Kuesioner II) pemberian suplemen Kalsium tercantum dalam Lampiran, dan reratanya dapat dilihat pada Tabel $5 .{ }^{10}$

Tabel 5 Rerata Skor Gejala SPM Sebelum dan Sesudah Pemberian Suplemen Kalsium ${ }^{10}$

\begin{tabular}{lccc}
\hline Kelompok & Kuesioner I & Kuesioner II & Selisih \\
\hline I Kontrol Negatif & 251,57 & 249,71 & 1,86 \\
II Pemberian Kalsium 500 mg/hari & 232,86 & 228,28 & 4,58 \\
III Pemberian Kalsium 1.000 mg/hari & 217,86 & 212,86 & 5 \\
IV Pemberian Kalsium 2.000 mg/hari & 252 & 240,86 & 11,14 \\
\hline
\end{tabular}

Dari tabel di atas, diketahui bahwa penurunan skor penghitungan gejala SPM paling besar didapatkan pada kelompok IV. Untuk mengetahui apakah kadar kalsium darah memengaruhi gejala SPM, maka dilakukan uji Kruskal Wallis berdasarkan hasil perhitungan angka melalui kuesioner, hasilnya $F$ hitung $19,004, p=0,0001$. Nilai $p \leq 0,05$ menunjukkan bahwa terdapat perbedaan yang signifikan antara kelompok kalsium dengan kontrol. Kemudian dilanjutkan dengan uji Mann Whitney. Hasil menunjukkan bahwa semua kelompok perlakuan (II, III, IV) berpotensi untuk menurunkan angka gejala sindroma premenstruasi bila dibandingkan dengan kelompok kontrol $(\mathrm{p}<0,05){ }^{10}$

\section{Diskusi}

Kadar kalsium nyata berhubungan dengan gejala SPM karena pada keadaan hipokalsemia sistem saraf menjadi semakin peka, sebab penurunan permeabilitas membran saraf terhadap ion natrium meningkat, menyebabkan perangsangan aksi potensial mudah terjadi. ${ }^{13}$ Kadar kalsium dalam darah di bawah normal disebut hipokalsemia. Gejala dari hipokalsemia di antaranya kram otot, kelelahan, perubahan nafsu makan dan perubahan irama jantung. ${ }^{14}$ Penurunan kalsium darah dapat disebabkan karena gangguan regulasi kalsium dalam darah, defisiensi PTH, seperti pada hipotiroidisme primer, atau vitamin D dan kurangnya asupan kalsium. ${ }^{15}$ 


\section{Research Article}

Penelitian terdahulu menunjukkan bahwa sejumlah zat gizi mikro antara lain kalsium, berpengaruh terhadap gangguan mood dan perilaku yang berlangsung selama SPM. Penelitian yang dilakukan Thys-Jacobs pada tahun 1998 terhadap 472 perempuan dengan pemberian 1.200 mg kalsium karbonat per hari selama 3 siklus, terbukti mampu meringankan gejala-gejala SPM sebesar $48 \%$ dari skor total dibandingkan dengan placebo. ${ }^{1}$ Penelitian terhadap anak SMA di Bogor, menunjukkan tidak ada hubungan antara pola kebiasaan makan dengan SPM, namun terdapat hubungan yang signifikan antara asupan kalsium dan vitamin B pada penderita SPM. Asupan tinggi kalsium dan vitamin B terbukti menurunkan gejala SPM. ${ }^{16}$ Penelitian yang dilakukan terhadap mahasiswi di Semarang, menunjukkan tidak terdapat hubungan asupan vitamin B6, kalsium, dan magnesium dengan kejadian SPM ( $p=0,270 ; p=0,700 ; p=0,489) .{ }^{17}$

Suplementasi kalsium adalah pengobatan sederhana dan efektif untuk SPM, dan terbukti mengurangi hampir semua gejala fase luteal. ${ }^{18,19}$ Untuk sebagian besar wanita, gejala dapat mereda atau berkurang dengan cara perubahan gaya hidup, seperti pengaturan pola makan, olah raga, obat-obatan yang mengandung hormon atau zat psikotropik. ${ }^{20}$ Pada orang dewasa, saran pengelolaan kondisi hipokalsemia pada SPM dimulai dengan edukasi dan perubahan gaya hidup. ${ }^{21,22}$ Pemberian kalsium akan lebih baik apabila disertai vitamin D, secara nyata terbukti mengurangi gejala SPM. ${ }^{2}$

Suplemen kalsium yang dipilih dalam penelitian ini adalah dalam bentuk kalsium laktat. Suplemen kalsium yang paling terkenal adalah bentuk kalsium sitrat dan kalsium karbonat, akan tetapi masing-masing sediaan memiliki perbedaan dan keunggulan tersendiri seperti jumlah kandungan kalsium, kemudahan suplemen diabsorpsi tubuh, dan harga. ${ }^{23}$

Dari hasil penelitian ini, dapat dilihat bahwa asupan kalsium dalam asupan makanan per hari berhubungan dengan kalsium dalam darah namun tidak memberikan pengaruh secara langsung terhadap gejala SPM karena ada banyak faktor yang dapat mempengaruhi absorpsi dan metabolisme kalsium. Pemberian tablet kalsium $1.000 \mathrm{mg} / \mathrm{hari}$ dan $2.000 \mathrm{mg} / \mathrm{hari}$ menyebabkan peningkatan kadar kalsium dalam darah secara signifikan $(\mathrm{p}<0.05)$. Gejala SPM mengalami penurunan secara signifikan pada semua pemberian suplemen kalsium $(500 \mathrm{mg} / \mathrm{hari}$, $1000 \mathrm{mg} /$ hari dan $2000 \mathrm{mg} / \mathrm{hari}$ ) ( $\mathrm{p}$ < 0.05), namun penurunan gejala SPM paling besar (skor gejala 11,142) terlihat pada pemberian tablet kalsium $2000 \mathrm{mg} / \mathrm{hari}$. Dosis ini masih berada dalam rentang dosis yang aman, karena batas atas dari dosis harian kalsium yang masih bisa ditoleransi oleh tubuh menurut Food and Nutrition Board untuk wanita dewasa usia 19-50 tahun adalah $2500 \mathrm{mg} .^{24}$

Penelitian yang dilakukan memiliki beberapa keterbatasan yang menyebabkan hasil penelitian sulit dibandingkan dengan hasil penelitian lain. Keterbatasan dalam penelitian ini 


\section{Research Article}

antara lain: jumlah subjek penelitian yang kurang, adanya faktor stres dari subjek, tidak ada pemilahan kelompok menurut derajat keparahan SPM serta siklus dan fluktuasi hormonal yang berbeda-beda pada tiap subjek dapat mempengaruhi hasil penelitian. Kadar vitamin D yang berpotensi memengaruhi absorbsi kalsium juga belum disinggung. Hasil penelitian Kia 2016 menyatakan bahwa kadar vitamin D yang rendah dapat berpengaruh pada keadaan SPM. ${ }^{25}$

\section{Simpulan}

Dari penelitian ini, diperoleh simpulan bahwa terdapat perbedaan kadar kalsium darah yang signifikan antara penderita SPM dan bukan SPM; terdapat perbedaan rerata asupan kalsium per hari yang signifikan antara penderita SPM dan bukan SPM, asupan kalsium berhubungan sangat signifikan dengan kadar kalsium darah pada kejadian SPM dan pemberian kalsium memengaruhi kadar kalsium darah serta menurunkan gejala SPM.

\section{Daftar Pustaka}

1. Ramadani M. Premenstrual syndrome, studi literatur. Jurnal Kesehatan Masyarakat. 2012;7(1): 21-5.

2. Bertone-Jhonson ER, Hankinson SE, Bendich A, Johnson SR, Willett WC, Manson JE. Calcium and vitamin D intake and risk of incident premenstrual syndrome. Arch Intern Med. 2005;165:1246-52.

3. Christiany I, Hakimi M, Sudargo T. Hubungan status gizi, asupan zat gizi mikro (kalsium, magnesium) dan hubungannya dengan sindroma premenstruasi pada remaja putri SMU Sejahtera di Surabaya. Melalui https://jurnal.ugm.ac.id/jgki/article/view/17685. Diunduh 20 September 2016

4. Taufikasari DM. Pengaruh tingkat konsumsi (vitamin C, magnesium, asam lemak Omega 6), aktivitas fisik dan olahraga dengan sindrom pramenstruasi di SLTP Hidayatullah Semarang. 2005. Melalui http://eprints.undip.ac.id/4877/1/2669.pdf. Diunduh tanggal 26 November 2011.

5. Bardosono S. Gizi sehat untuk perempuan. Jakarta: FKUI. 2006. Melalui http://drsuparyanto.blogspot.com/2010/07/konsep-premenstrual-syndrome-pms.html. Diunduh tanggal 11 Des 2014.

6. Schoor VJRN, Ficnk P. Monthly blues-premenstrual syndrome. Incorporating Pharmacy Management. 2002. Melalui www.medphar.co.2a/sapj/2002/juli/pms.html. Diunduh tanggal 30 Agustus 2014.

7. Shamberger RJ. Calcium, magnesium, and other elements in the red blood cells and hair of normals and patients with premenstrual syndrome. Biol Trace Elem Res. 2003;94(2):123-9. Available at https://www.ncbi.nlm.nih.gov/pubmed/12958403. cited November 26th 2016

8. Wardani KRP. Hubungan kadar kalsium dalam darah dengan sindroma premenstruasi pada mahasiswi Fakultas Kedokteran Universitas Kristen Maranatha 2010. Universitas Kristen Maranatha Repository. Diunduh tanggal 27 Maret 2016.

9. Purba BM. Hubungan rerata asupan kalsium per hari dengan kadar kalsium darah pada perempuan dengan sindroma premenstruasi Universitas Kristen Maranatha. Repository. Diunduh tanggal 27 Maret 2016.

10. Apreza RT. Pengaruh pemberian kalsium terhadap penurunan gejala sindroma premenstruasi pada mahasiswi Fakultas Kedokteran Universitas Kristen Maranatha. 2012. Universitas Kristen Maranatha Repository. Diunduh tanggal 27 Maret 2016.

11. Brahmbhatt S, Sattigeri BM, Shah H, Kumar A, Parikh D. A prospective survey study on premenstrual syndrome in young and middle aged women with an emphasis on its management. Int J Res Med Sci. 2013; 1(2): 69-72.doi: 10.5455/2320-6012.ijrms20130506.

12. Fikawati S, Syafiq A, Puspasari P. Asupan kalsium pada remaja. Universa Medicina. FKMUI. 2005;24(1).

13. Guyton AC, Hall JE. Buku ajar fisiologi kedokteran.Edisi 11.Jakarta: Penerbit Buku Kedokteran EGC.2007; p.1064-72

14. Ganong WF. Review of medical physiology. $21^{\text {st }}$ ed. San Francisco: McGraw-Hill. 2003.

15. Philip JG. Calcium salts. Prescriber's Letter Document \#160313. 2000. Melalui http://faqs.org/nutrition/CaDe/Calcium.html. Diunduh tanggal 31 Agustus 2015.

16. Utari D. Hubungan asupan gizi dengan sindrom pramenstruasi pada remaja putri di SMA Bina Insani Bogor. IPB repository.2013. URI:http://repository.ipb.ac.id/handle/123456789/66291. Diunduh tanggal 28 Maret 2014. 


\section{Research Article}

17. Septiani TA, Yekti W. Hubungan asupan vitamin B6, kalsium, dan magnesium dengan kejadian premenstrual syndrome (PMS); studi pada mahasiswi Program Studi Ilmu Gizi FK UNDIP Semarang. UNDIP Repository. Undergraduate thesis, Program Studi Ilmu Gizi.2009. Diunduh tanggal 28 Maret 2014.

18. Ward MW, Holiman TD. Calcium treatment for premenstrual syndrome. Ann Pharmacother.1999;33(12):13568.

19. Thys-Jacobs S, Starkey P, Debra Bernstein D, Jason Tian J. Calcium carbonate and the premenstrual syndrome: effects on premenstrual and menstrual symptoms. Am J Obstet Gynecol.1998;179(2): 444-52.

20. Frackiewicz EJ, Shiovitz TM. Evaluation and management of premenstrual syndrome and premenstrual dysphoric disorder. J Am Pharm Assoc (Wash). 2001;41(3):437-47.

21. Rapkin AJ. New treatment approaches for premenstrual disorders. Am J Manag Care. 2005;11(Suppl):S480-91

22. Rapkin AJ, Mikacich JA. Premenstrual syndrome in adolescents: diagnosis and treatment. Pediatr Endocrinol Rev. 2000;3 Suppl1:132-7.

23. Ehrlich SD. Calcium. 2011. Melalui http://www.umm.edu/altmed/articles/calcium-000290.htm. Diunduh 20 Mei 2014.

24. Ross AC, Manson JE, Abrams SA, Aloia JF, Brannon PM, Clinton SK, et al. 2011. The 2011 Report on dietary reference intakes for calcium and vitamin D from the Institute of Medicine: What Clinicians Need to Know. $\mathbf{J}$ Clin Endocrinol Metab. 2011; 96 (1):53-8.

25. Kia AS, Amani R, Chregian B. The association between the risk of premenstrual syndrome and vitamin D, calcium, and magnesium status among University Students: a case control study. Health Promot Prespect. 2015;5(3):225-30 